\title{
Discipline Understanding in Islamic / Traditional Education
}

\author{
Mehmet Okutan \\ Fatih Education Faculty, Trabzon University, Trabzon, Turkey \\ E-posta:dr.mokutan@hotmail.com
}

\begin{abstract}
The sources of Islamic education, Qur'an, Sunnah and Islamic education literature, contains very clear suggestions on teachers' understanding of discipline in teaching. Accordingly, it is expected that these suggestions will be embodied in the attitudes and behaviors of teachers, especially teachers who are obliged to provide religious education. According to the Qur'an and Sunnah, which is the main source of Islamic education, the Messenger of Allah (SA) is an educator and teacher who is sent to Muslims. The Messenger of Allah (S.A.V.), who was sent as a teacher, underlined that he was a compassionate teacher and that if we compassion as a teacher, we would see compassion from everyone, primarily from the students. Hz. Muhammad (S.A.) was the teacher whom Muslims were able to open up all kinds of problems and trust. The general method of his teaching was to read verses from the Qur'an and then to comment and explain them in an invigorating and ecstatic manner with a sweet voice, and to invite those who listen to him to believe. Those who listened to him were also his disciples. It was seen that there was a very important trust relationship with his students. Where authority exists, the discipline of discipline at the same time is considered a very important situation in the Islamic education tradition. The Qur'an reveals His Messenger of Allah as a soft-tempered person to those around him through a compassion from Allah. It is a community that starts with the family and covers all of its companions. According to this, compassion appears to be the most important factor in his discipline. Compassion is the most important feeling that contributes to the life of "love" culture in the management of teaching. The Messenger of Allah emphasized the importance of compassion in his education by saying, "Allah has sent me not as complicating and surprising, but as an educator (teacher / teacher) and facilitator". In another hadith, yönetici If any ruler treats the society in which he is assigned with the duty of governing with softness, Allah will treat him in the same way on the day of account. Uştur This can be achieved by providing a positive understanding of discipline in the classroom. According to Ibn Sina, all attention should be paid to protecting the child's morality. This is by avoiding behaviors that will leave the child with excessive nerve, severe fear, sadness and insomnia. Such behavior can be revealed by the positive discipline of the teaching service in the classroom. Although there is a license to punish children in order to ensure discipline in Islamic education, the use of punishment in Islamic education is not recommended. Hz. It is very important that the Prophet strokes the head of the children - even after their misconduct. The method of this study was determined as literature review. The study of the sources recorded in the literature of Islamic education and the practices of the teachers responsible for providing Islamic education in the education system were determined as the method of this study.
\end{abstract}

Keywords: Islamic Education, Discipline, Traditional Education

DOI: $10.7176 / J S T R / 5-12-14$

\section{İslami/Geleneksel Eğitimde Disiplin Anlayışı}

\begin{abstract}
Özet
İslami eğitimin kaynakları olan Kur’an, sünnet ve İslâmî eğitim alanyazını, öğretmenlerin öğretimdeki disiplin anlayışlarına ilişkin çok açı önerileri barındırmaktadır. Buna göre, öğretmenlerin, özellikle de din eğitimi vermekle yükümlü öğretmenlerin tutum ve davranışlarında bu önerilerin somutlaşması beklenir. İslami eğitimin temel kaynağı olan Kur'an ve Sünnete göre, Allah Resulü(S.A.) Müslümanlara gönderilmiş bir eğitimci, bir öğretmendir. Bir öğretmen olarak gönderilen Allah Resulü(S.A.V.),
\end{abstract}


merhamet ederek öğretmenlik yaptığının altını çizerek, öğretmen olarak merhamet edersek, öncelikle öğrencilerden olmak üzere, herkesten merhamet göreceğimize vurgu yapılmaktadır. Hz. Muhammed(S.A.) Müslümanların her türlü sorunlarını açabildikleri ve güven duydukları öğretmenleriydi. Onun öğretiminin genel yöntemi, tatlı sesiyle istiğrak ve vecd içinde önce Kur'an'dan ayetler okumak, sonra da bunları tefsir edip açıklamak ve kendisini dinleyenleri inanmaya davet etmekti. Kendisini dinleyenler, aynı zamanda onun öğrencileriydi. Görülüyor ki, öğrencileri ile arasında çok önemli bir güven ilişkisi söz konusu idi. Otoritenin olduğu yerde, aynı zamanda disiplinin de egmen kılınması İslami eğitim geleneğinde çok önemli bir durum olarak değerlendirilmektedir. Kur'an Allah Resulü'nü “Allah'tan gelen bir merhamet sayesinde çevresindekilere karşı yumuşak huylu bir kişi olarak anlatır. Çevresindekilerden kasıt, aile efradından başlayan ve bütün ashabını kapsayan bir topluluktur. Buna göre, onun öğretimindeki disiplin anlayışında etkili olan en önemli unsur, merhamet olarak ortaya çıkmaktadır. Merhamet, öğretimin yönetilmesinde, "sevgi" kültürünün hayat bulmasına katkı yapan en önemli duygudur. Allah Resulü, "Allah beni zorlaştırıcı ve şaşırtıcı değil, lakin eğitimci (muallim/öğretmen) ve kolaylaştırıcı olarak göndermiştir" buyurmak suretiyle onun eğitiminde merhametin önemine vurgu yapmıştır. Başka bir hadiste, "Herhangi bir yönetici yönetme görevi ile görevlendirildiği topluma yumuşaklıkla muamele ederse, Allah da hesap gününde ona aynı şekilde muamele eder" diye buyrulmuştur. Bu durum da sınıfta olumlu bir disiplin anlayışının sağlanması ile gerçekleş̧irilebilir. İbni Sina'ya göre bütün dikkatin çocuğun ahlakını korumaya sarf edilmesi gerekir. Bu da çocukta aşırı sinir, şiddetli korku, üzüntü ve uykusuzluk bırakacak davranışlardan sakınmakla olur. Böylesi bir davranış, sınıftaki öğretim hizmetinin olumlu disiplin marifetiyle ortaya çıkarılabilir. İslami eğitimde disiplinin sağlanması amacıyla, çocukların cezalandırılabileceğine ilişkin ruhsat olmasına rağmen, cezanın İslami eğitimde kullanılması önerilmez. Hz. Peygamber'in çocukların -yaptıkları yanlış hareketten sonra bile- başını okşaması son derece önemlidir. Bu çalışmanın yöntemi, alanyazın taraması olarak belirlenmiştir. İslami eğitimin alanyazında kaydedilmiş kaynakların taranması ve eğitim sisteminde İslami eğitimi vermekle yükümlü öğretmenlerin uygulamaları, bu çalışmanın yöntemi olarak tespit edilmiştir.

Anahtar kelimeler: İslami Eğitim, Disiplin, Geleneksel Eğitim

\section{Disiplin Kavramı}

Disiplin eğitimin vazgeçilmez unsurlarından olup(Işıkdoğan 2014), yaşamı ancak topluluk halinde sürdürebilen insan için oldukça önemli bir olgudur(Şimşek 2014).

Günlük yaşamda "düzen" anlamında kullanılan disiplin kavramı(Hesapçığlu 1988: 303), Latince "disciplina" sözcügü̈nden türemiş bir kavramdır(Erdem 2010: 83, Erzurum 2011). Fransizcadan Türkçeye geçen disiplin, çocuğa istenilen davranışların ve alışkanlıkların kazandırılmasıyla, çocuğun ahlaki gelişiminin sağlanmasını, çocuğun kendi hareketleri ve sorumluluklarıyla sonuçları kabul etmesini sağlar(Seven, Altınışık ve Elmas 2018).

Disiplin kelimesi sözlüklerde, "adab-1 muaşeret, eğitmek, idare etmek, intizam, itaat, nizam, talim ve terbiye, tekdir, yetiştirmek, yola getirmek, yol yordam gibi anlamlara geldiği gibi(Ay; 230), bir toplulukta uyulması gereken yasa ve kuralların tümü olarak da bilinir. Disiplin bir toplumun üyelerine(özellikle asker ve öğrencilere ya da insanın kendi kendine uygulamasını buyurduğu davranış kurallarının tümü anlamına gelir(Öncül 2000). Çocuğun kendi kendine çekidüzen vererek, amacına göre daha etkili ya da ideal çalışabilir hale gelmesi olan disiplin "içsel disiplin" ise geçerlidir(Binbaşığlu 1993: 200). Disiplinsizliğin düzensizlik getireceğine inanan Russell(2003: 209) da eğitimde bir ölçüde otorite ve disiplinin uygulanması gerektiğini savunmuştur. Disiplin, bir insan topluluğunun, belli bir düzen içinde yaşamasını sağlamaya yönelik olarak konulan kurallara ve bu kuralların uygulanması için alınan tedbirlere denir(Okutan, 1997; 31). Başka bir ifade ile bir topluluğun mevzuatı ile düzene ilişkin yazılı ve yazısız kurallarına uyulması durumuna disiplin denir. Disiplin, kişileri, gerek kendi davranışlarına çekidüzen vermeye, gerekse içinde yaşadıkları topluluğun saygı gösterdiği ahlâk ve hukuk hükümlerine yapıcı faaliyetlerde bulunmaya zorlayan aktif özelliği olan "görünmez kuvvet" niteliği taşır. Disiplin, öğrencinin kendi kendini bir düzene sokması sonucu sağlanabilirse gerçekten disiplin olur. Buna "iç disiplin", ya da "otokontrol" diyoruz. Disiplin mutlak itaatle değil, karşllıklı saygı ve sevgi ilişkisi içinde sağlanabilirse, öğretmen ve öğrenci için anlam kazanabilir. Aslına bakılırsa "mutlak itaat" hiç kimse için söz konusu değildir; ana-baba, öğretmen, okul müdürü, vb. hiç kimse için mutlak itaat yok, karşılıklı sevgi ve saygıya dayalı itaat vardır. Bu da sınıf yönetiminin küçük ama önemli bir boyutunu oluşturmaktadır.

Disiplinin amacı, bireyin içinde yaşadığı topluluğun(okul, sınıf), kurallarına uymak suretiyle, kendi kendini disiplinleştirmesi veya kişiyi toplumun genel düşünüş ve davranışlarına uymasını sağlamak için 
onu bu düşünce ve davranışlara yatkın hale getirmektir(Alaylığlu ve Oğuzkan 1976). Disiplin ayrıca, bireyin içinde yaşadığı toplumun gerektirdiği din, hukuk, ahlâk ve disiplin kurallarına uyması; öğrencinin de okulda ilgili mevzuata uygun davranmasıdır. Ayrıca öğrenciye, içinde bulunduğu topluluktan, sınıftan başlayarak, hayatta, her zaman ve her yerde kendiliğinden uymasını sağlar(Bayraktar 1987; 244).

Bu haliyle disiplin öğrenciye düzenli yaşamasını öğretir. Disiplin öğrenciye, sınıftan başlayarak, hayatın her alanında topluluk halinde yaşarken, o topluluğun kabul ettiği kurallara ve ilkelere kendiliğinden ve kolayca uymaya yardım edecek anlayış ve alışkanlıklar kazandırır. Bireyin içinden gelerek kurallara uymasını öğrenmesi, bulunacağı her toplumda, "otokontrol” veya "iç disiplin" mekanizmasının çalıştırılmasına önemli katkı sağlar.

Disiplinde itaat esastır. Ancak disiplinde "mutlak itaat" sözkonusu değildir. Disiplindeki itaat, karşılıklı sevgi ve saygıya dayalı bir itaattir. Bu şekildeki bilinçli itaat, disiplinin temelini oluşturur. Geleneksel eğitimle modern eğitimin disiplin anlayışındaki farklılık, disiplini sağlama yöntemleri ile ilgili olduğu bilinmektedir. Buna göre disiplin, yalnızca uyulması gereken kurallar listesinden çok daha geniş bir anlam ifade etmektedir. Amaçlı etkinlikler, uygun çevre, birlikte çalışma alışkanlığı, kendi kendini kontrol etme gibi kavramlar, disiplin kavramı içinde önemli yer tutmaktadır(Küçükahmet, 1994; 84).

Birçoklarına göre disiplin, öğrencilerin uslu, sessiz durmasını; verilen buyrukları koşulsuz yerine getirmesini; kimseyi rahatsız etmeden dinlemesini sağlamak anlamındadır. Bu anlayıştaki bir müdür, öğretmen, okulunda, sınıfında öğrencilerini yeğin bir baskı altında tutmaya çalışır. Böyle bir disiplin anlayışı, okul müdürünü, öğrencilerde korku ve kaygı yaratmaya yönelik girişimlerde bulunmaya yöneltir. Eğitimde disiplin, öğrenciye hangi davranışın istenilir olduğunu gösterip öğretmek, öğrencinin bu davranışını yapıp yapmadığını izlemek; davranışı beklenenden iyi yaptığında ödüllendirmek, yapmadığında da onu cezalandırmaktır. Bu anlamda disiplin, istenen davranışı öğrenciye öğretmek ve yerleştirmektir. Böyle bir disiplin eğitim ile eş anlamlıdır. Eğitimde ödüllendirme, öğrenciyi istenen davranışı yapmaya özendirmeyi ve yaptıktan sonra da sürdürmeyi içermektedir. Ödüllendirme, önceden belirlenen kurallara göre, adil ölçülerle verilmelidir. Ödül rüşvet değildir. Ödül haz veren tüm etkileri içerir. Eğitimde cezalandırma, istenmeyen davranışın yapılmasını caydırıcı, yasaklayıcı ya da istenilen davranışın yapılmasını güdüleyici etkileri içerir. Bu etkilerin bedensel acılar verecek türden olması beklenemez. Ama cezalandırıcı etkiler, kuşkusuz elem veren türdendir. Ödüllendirmenin kişiye haz veren etkilerden olmasına karşı, cezalandırma kişiye elem veren etkilerden oluşur. Disiplin, öğrencilerin davranışlarını yönlendiren bir dizi kuralların uygulanış derecesini bildiren bir dizi ölçütten oluşur. Bir davranışın. Okulun etkili bir disipline kavuşabilmesi için kuralların ve ölçütlerinin önceden belirlenmesi, bunların öğrencilerce algılanmasının sağlanması gerekmektedir( Başaran,1982; 145-146).

ABD Başkanı 1983 yılında ulusal bir forumda eğitimin iyileştirilmesi ve "eski moda disiplin" in tartışmaya açılması için bir çağrı yaptı: Amerika'daki okulların mali destekten çok birkaç temel reforma gereksinimleri var. İlkönce, eski moda disiplini dönmeliyiz... Daha sonra sert kurallar getirmeliyiz; ondan sonra bu kuralları uygulayacak öğretmenlerimizi desteklemeliyiz( Gordon, 2001; xiv-xv). ABD Başkanı'na sunulan bir raporda, okullardaki şiddet ve düzensizlik dile getiriliyor ve disiplin sorunlarıyla uğraşan öğretmen ve yöneticilerin otoritelerinin artırılması üzerinde duruluyordu(Gordon 2001: xv). Buna göre disiplin dünyanın her yerinde eğitimin vazgeçilmez bir öğesi olarak kabul edilmektedir.

Disiplin kelime anlamı, "eğitmek" tir ve gençlerin eğitilmeye ihtiyacı vardır. Bu eğitimin büyük bir yüzdesi kelimeler vasıtasıyla verilir fakat bir kısmı da fiziksel yönden verilmelidir. Çocuğunuz size karşı bilerek ve isteyerek itaat etmezse, işte bu aşamada fiziksel tedbirin alınması gerekir. Bu yöntem, mesajınızı karşı tarafa iletmenin en emin ve hızlı yolu olacaktır. Popoya atılan bir şaplak, ne demek istediğinizi çocuğunuza iletmenin en kolay ve hızlı yolu olacaktır. Sadece çocuğunuzun size meydan okuduğu veya itiraz ettiği durumlarda ona bir şaplak atmanız çok büyük bir önem taşır(Ziglar 1998: 371). Eğitimcilere düşen iş, çağın ihtiyaçlarına uygun bir disiplin ve itaat terbiyesi sistemi bulmaktır.

Disiplin ve itaat dışardan zorla verilmemelidir. Disiplini insanın en derin benliğine mal edebilmelidir. Disiplin, insanı, kendi şahsi kaprislerinden kurtarıp nefsine hâkim kıldıracak bir vasıta gibi görünmelidir Sınıf yönetimi ne zaman etkili bir biçimde uygulanırsa, öğrenciler daha az yaramazlık ve istenmeyen davranışlar göstererek disiplin sorunlarına neden olurlar. Sınıf öğrencilerin dersle ilgili kalmasını sağlamak için disiplinli bir ortam olmalıdır. Disiplin, sınıfta, öğrencilerin davranışlarına rehberlik etmek, sınırları belirlemek, öğrencilerin kendilerine, başkalarına ve çevresindeki dünyaya nasıl bakacaklarını öğrenmelerine yardımcı olmakla ilgilidir(Russell 2003: 209).

Çocuğun gelişiminde büyükler tarafından örgütlenen yaşam düzenini ifade eden disiplin, eğitimin temel kavramlarından biridir. Disiplin sadece buyruklar verme, cezalandırma veya ödüllendirme yoluyla belli bir davranış elde etmek değildir. Sadece itaat etmeyi öğrenmek, gelecekteki yaşam için çocuğa yetmeyecektir. Çünkü insan, kendi hayatını, kendi başına düzenlemek ve denetlemek için bağımsız olmayı da öğrenmek zorundadır. Disiplin olgusu içinde, otorite ve özgürlük alanları, birbiri içine girmiş 
durumdadır. Disiplin doğal dürtüleri doyumsuz bırakmak, engellemek, bastırmak değildir. Böyle anlaşılan disiplin neden olacağı çatışmalar yüzünden kişiliğe zarar verecektir.

Otorite sahibi olmak başkadır, otoritarizm uygulamak başkadır. Otoritesiz eğitim olmaz, ancak "otoriter" olmak, disiplini sağlamada kabul edilmeyen bir tutumdur.

\section{Sinıf Yönetimi ve Disiplin}

Disiplin kavramı öncelikle "ceza”, "katı kurallar", "şiddet” gibi kavramları çağrıştırdığından bazı uzmanlar, sınıf yönetimi ile disiplini ilişkilendirmemektedir. Bu anlayışın sonucu da sınıf yönetimi ders kitaplarının çoğunda "disiplin" konusu yer almamaktadır.

Eğitim yönetiminin en temel basamağında yer alan sınıf yönetiminin önde gelen isimlerinden H. Başar bu konuda şunları söylüyor: Sınıf yönetimi işleri arasında, "Sınıfta disiplin sağlama" işleri yoktur; çünkü sınıfta disiplin olmaz, düzen olur. Disiplin askerde olur, okulda değil. Sınıfta disiplin korku ve kaygıyı yükseltir, bunlar yalanı artırır. Disiplin sınıfta girişimi, cesareti, yaratıcılığı, gelişimi engeller, demokrasiyi amaçlarından saptırır. Bu nedenle okulda ve sınıfta disiplin değil, düzen olur. Disiplin sıkı düzendir. Sınıf düzeninin sağlanması, sınıf yönetimi işlerinin çok küçük bir dilimini oluşturur(Başar, 2012; 16-17). Katı kuralların, ceza anlamındaki disiplinin askerde olduğu doğru olabilir. Ancak "düzen” ve "eğitim" anlamına gelen disiplinin okulda olması doğaldır. Hatta okul, düzenli ve disiplinli bireyler yetiştirme misyonuna sahip bir kurumdur.

Sınıf yönetimi, sınıf kurallarının belirlenmesi, uygun bir sınıf düzeninin sağlanması, öğretimin ve zamanın etkili yönetilmesi ve öğrenci davranışlarının denetlenerek olumlu bir öğrenme ikliminin geliştirilmesi süreci biçiminde de tanımlanan sınıf yönetimi, sınıfın öğretime uygun hale getirilmesi ve sınıftaki insan ve madde kaynaklarını etkili bir şekilde kullanmayı gerektiren bir etkinlik olarak kabul edilmesi ve öğretmenin yönetimsel becerisini sınıf ortamında kullanmasını zorunlu kılmaktadır(Çelik 2003: 4). Öğretmenin başarısı, öğretimi nasıl yönettiği ile ilgili olup, öğretimin iyi yönetilmesi, sınıfın başarılı bir şekilde yönetildiği anlamına gelir. En seçilmiş öğrencilerden bir sınıf oluşturun, sınıfı bütün teknolojik araç-gereçlerle donatın, kitap, vb. malzemeyi eksiksiz bir şekilde sağlayın. Bu sınıfın, öğretmensiz bir yere varamayacağı gibi, etkili bir yöneticilik bilgi ve becerisine sahip olmayan bir öğretmenle de istenen bir yere varması güç, hatta imkânsızdır(Okutan 2010: 3). Çünkü otoritesiz öğretimin başarılı olması mümkün değildir; otorite ise, öğretmenin sınıfı liderce yönetmesi anlamına gelir. Otoritesiz bir öğretmenin sınıfında disiplinsizliğin olacağı açıtır. Disiplinin olmadığı sınıfın yönetimi, kendiliğinden çıkılmaz bir hal almaya müsaittir.

Yapılan araştırmada öğrencilerin başarısını \%50 kendileri, \%30 öğretmenler, \%5 ya da \%10 aile ortamı ve ilişkileri, \%5 ya da \%10 arkadaş ilişkileri etkilediği ortaya çıkmıştır(Mansor ve diğerleri 2012). Görüldügü gibi öğretmenlerin \%30’luk etkisi, onların kalitesini ve etkisini açıkça ortaya koymaktadır. Öğrencinin başarısında bu denli bir etkiye sahip olan öğretmenin, aslında bu etkisinin sınıf yönetimi becerisinden kaynaklandığı söylenebilir.

Darling(2002)'in yaptığı araştırma gösteriyor ki, öğretmenin etkili oluşu, tamamen öğrencinin başarısı ve sınıfiçi performansı ile ilgilidir(Mansor ve diğerleri: 2012).

Sınıf yönetimi, aynı zamanda davranış yönetimi içerir. "Davranış yönetimi” disiplinin anlamlarından biridir. Bu da sınıf yönetimi ile disiplinin ilişkisini açıkça ortaya koymaktadır. Disiplin, sınıf yönetiminin önemli bir parçasıdır ama kendisi değildir(Mansor ve diğerleri 2012). Günümüzün ideal sınıfı çok farklı sesler ve görüntüler içeriyor(Kahn, 2018: 174). Hatta günümüzün ideal okullarında "gürültü" tercih edilen bir durumdur. Önemli olan, her öğrenciden çıkan sesin, öğretmenin sınıf yönetimi maharetiyle ahenkli bir müziğe dönüşmesini sağlamaktır.

Deneyim düzeyleri ne olursa olsun, öğretmenlerin karşılaştı̆̆ı en büyük sorunlardan biri sınıf yönetimi( Huth 2015) olduğu gibi, yeni öğretmenlerin de en fazla yardım talebinde bulundukları konular, sınıf yönetiminde karşılaştıkları problemlerle ilgilidir(Yılmaz 2010: 417). Yeni sınıf yönetimi yaklaşımları, öğretmenin sınıfta esnek olmasını gerektirdiği gibi, öğrencilerin birbirinden öğrenmesini sağlayacak bir sınıf düzeni oluşturmayı da gerekli kılmaktadır. Yeni eğitim sisteminin sınıflarında öğretmenin yönetici değil, rehber olduğu, öğrencinin kendi kendini yönlendirdiği eğitim durumları ortaya çıkmıştır( Kahn 2018: 153). Ne ki, bu durumun, öğretmenin sınıfta etkisiz hale geldiği, sınıfı yönetme işinin öğrencide kaldığı anlamına alınmaması gerektiği vurgulanmalıdır. Yeni sınıf yönetiminde, öğretmen yönetilen, öğrenci yöneten konumuna gelme yanlışlığına düşülmemelidir.

Geleneksel öğretmen merkezli eğitim-öğretimin yerini, öğrenci merkezli eğitim-öğretime bıraktığ1 günümüz sınıflarında, öğretimin yönetimi, daha bir zorlaşmış görünmektedir. Deneyimli öğretmenlerin bile zorlandığı sınıf yönetiminin kaynağında, öğretmenlerin öğrencilerle insiyatifi paylaşamamaları sorunu yatmaktadır(Okutan 2010: 2). Günümüzde sınıflar, öğretmen merkezli eğitimdeki "patronca-tek adam yönetimi” yaklaşımı ile yönetilmeye uygun değildir. Çünkü günümüz eğitiminde sınıfların yönetimi, tek adam yönetiminden liderce yönetime, hatta yönetişim yaklaşımlı yönetime evrilmişstir. 
Geleneksel eğitimde öğretmenler, sınıfın tek hâkimi olarak, öğrencilere sadece ders anlatıp, otoriter bir sınıf yönetimi sergilemişlerdi. Bugün ise öğretmenler, deneyimli olmalarına rağmen, tek taraflı ders anlatarak, sınıfı yönetmede başarılı olamamaktadırlar. Çünkü günümüz eğitiminde "öğrencilerle ders anlatmak" yaklaşımı geçerli hale gelmiştir. Bu durum da, öğretmenlerin sınıf yönetimi başarılarını zorlaştırmaktadır. Günümüz sınıflarında, öğretmen, sınıfı tek adam gibi değil, orkestra şefi gibi yönetmedikçe, başarılı olma şansı düşüktür. Geleneksel sınıflardaki sessiz sedasız sınıfları kolayca yönetip öğretimi gerçekleştiren öğretmen, günümüzde, “gürültülü” sınıflarında sınıfı yönetmede, kendini başarısız olarak değerlendirmektedir. Günümüzün öğretmeni, ister deneyimli, ister deneyimsiz olsun, sınıfta ortaya çıkan farklı sesleri, amaçlar doğrultusunda yönlendirerek, istenilen seviyeye getirmekle yükümlüdür. Bu yükümlülük, öğretmenlerin sınıf yönetimi etkinliğini zorlaştırmakta ve öğretmenlerin, sınıf yönetiminde kaosa sürüklenmelerine neden olmaktadır. Öğretmen farklı öğrenci özelliklerini, sorunlarını, tepkilerini, tartışmalarını yönlendirerek, dersin amaçları doğrultusunda, istenen yere gelmesini sağlamak zorundadır. Bu durum aslında bir yönetim eylemidir; sınıfı yönetmektir. Sınıf ortamında ortaya çıkan durum, bir yönetim olduğuna göre, bunun adı da sınıf yönetimidir. Yönetişim, sınıftaki bütün öğrencilerin öğretime katılması anlamına gelir. Sınıfta bulunan bütün kaynakları en etkili ve verimli bir biçimde kullanabilme, önemli bir yönetim bilgi ve becerisi gerektirir. Bununla birlikte, öğretmenlik alan bilgisi ile ilgili yeni yaklaşımlardan da haberli olmak, günümüzde etkili öğretmen olmanın şartı olarak değerlendirilmelidir.

İyi yönetilmeyen ve disiplinsiz sınıflarda iyi öğretimin yapılması neredeyse imkânsızdır. Bu açıdan bakıldığında, sınıf yönetiminin ve disiplinin öğretimde ne kadar önemli olduğu anlaşılabilir. Sınıflar ne kadar iyi yönetilir ve disiplin sağlanırsa, o kadar iyi bir öğretim ortamı oluşabilir. Günümüz sınıflarında demokrasi kültürünün egemen olması zorunlu hâle geldiği için, otoriter öğretmenlerin sınıf yönetimi işi daha bir zorlaşmıştır. Öğrencilerin öğrenmeye istekli hâle getirilmesi, sınıfta demokrasinin bir yaşam biçimi hâline gelmesi anlamına gelmektedir. Sınıfta demokrasinin olması, bütün öğrencilerin birey olduğu ve her birinin bireysel özelliklerinin farklı olduğu gerçeğinin anlaşılması demektir. Demokrasinin olduğu sınıfta soru sormanın bilimin yarısı olduğuna inanılır. Bu demokratik sınıfta, öğrenciler, okulun yapısının ve vizyonunun oluşmasına katılmak yönünde teşvik edilir, öğrencilerin kendi öğrenmelerini ve yaşamlarını yönetebileceğine inanılır ve öğretmenin, etkinliklerinin yöneteni olmasından çok, bir danışman ve bir rehber olduğuna inanılır( Balme ve Bennis 2008: 192). Böyle yönetilen bir sınıf, aynı zamanda disiplinli bir sınıf da olacaktır. Geleneksel okuldaki baskıcı anlayış, bu sınıflarda öğrencinin merak duygusunu teşvik eden ve güçlenmesini sağlayan bir anlayışa evriliyordu. Öğrenciler disiplini bozmadan soru sorma, sorulan sorulara, yine düzeni bozmadan istediği gibi cevap verme özgürlüğüne sahiptirler. Böyle bir ortamda, etkili sınıf yönetiminin ortaya çıkma ihtimali her zaman yüksektir. Otoriter öğretmenin, otoritesini zayıflatmadan, ama otoriter olmadan, sınıfı yönetmesi zorlu bir iştir. Bu durumun ortaya çıkması için sınıfta demokrasi kültürünün bir yaşam biçimine dönüşmesi zorunludur. Böyle bir sınıfta, öğrencilerin öğrenme arzuları karşılanacak ve bireysel gelişimleri ile akademik başarıları istenen düzeye gelecektir. Böyle bir sonucun ortaya çıkmasında en önemli itici gücün, etkili sınıf yönetimi ve pozitif disiplinin olduğu kuşkusuzdur.

\section{Geleneksel/İslami Eğitimde Disiplin}

İslam'da eğitimin ilkesi, mutlak bilime, mutlak kudrete, mutlak iradeye sahip olan Allah inancıdır( Ayasbeyoğlu 1991:25). İslam'da talim ve terbiyenin amacı, inançlı, erdemli ve verimli insan yetiştirmektir(TDV, İ.A, 39.Cilt). İslam eğitim sistemi, inançlı, erdemli, verimli ve disiplinli insan yetiştirmeyi hedef edinmiştir. Bu hedeften dolayı İslami eğitim, yetişmekte olan bireylerin eğitimlerini önemsemiş, kadın erkek herkese eğitimi farz kılmıştır.

Kur'an Allah Resulü'nü “Allah’tan gelen bir merhamet sayesinde çevresindekilere karşı yumuşak huylu bir kişi(Al-i İmran: 159)” olarak anlatırken, O’nun için şu bilgiyi paylaşır: “ Andolsun ki, size kendi içinizden bir Peygamber gelmiştir. Sizin sıkıntıya düşmeniz ona pek ağır gelir. O size çok düşkün, müminlere karşı çok şefkatli ve çok merhametlidir(Tevbe: 128)." Yönetici konumunda olan herkesin, özellikle ilim öğreten öğretmenlerin öğrencilere, çok düşkün, şefkatli ve sevecen olmaları Kur'an'ın gereğidir. Buna göre "katı kurallar" anlamında bir disiplin değil, pozitif disiplinin eğitimde işe koşulması İslami eğitimin gereğidir. Allah Resulü(S.A.), pozitif disiplini uygulamada mahirdi. Onun öğretiminin genel yöntemi ve disiplin anlayışı, tatlı sesiyle, istiğrak ve vecd içinde önce Kur'an'dan ayetler okumak, sonra da bunları tefsir edip açıklamak ve kendisini dinleyenleri inanmaya davet etmekti(Özbek 1994: 22). Çevresindekilerden kasıt, aile efradından başlayan ve bütün ashabını kapsayan bir topluluktur. Buna göre onun öğretimi yönetmesi ve disiplin konusunda etkili olan en önemli unsur, merhamet olarak ortaya çıkmaktadır. 
Hz. Peygamber çocukları her zaman sevmiş, onların sevilmesini, öpülüp okşanmasını, onlara şefkat ve merhamet gösterilmesini istemiştir(Sahnun 1996: 47). Bu öneri, İslami eğitimde disiplin ve sınıf yönetiminin sevgiye dayalı olarak uygulanmasını ögütlemektedir.

Öğretmenlerin kızması ve gazabına göre hareket etmesi, ne çocukların terbiyesine şifa verir, ne de onun kalbine huzur getirir(Kabisi: 54). Görüldüğü gibi, İslami eğitimde aslolan terbiye etmek olup, bunun için şiddetten uzak durulmalı ve olumlu disiplin uygulanmalıdır.

Riyazu'l müteallim'de şöyle anlatılır: "Biz çocuktuk, Ebu Said el Hudri’yi gelir, ona soru sorardık. O şöyle derdi: 'Resulullah'ın tavsiye ettiklerine merhaba. Allah Resulü şöyle buyurdu: Dini bilgiler öğrenmek üzere size bir topluluk gelecektir. Onlara öğretin ve iyi davranın(Akt. A. Özel: 3. Cilt: 127). Eğitim-öğretim işlerinde öğrencilere, bilhassa küçük çocuklara sert davranmak ve katı kurallar anlamında bir disiplin uygulamak yanlıştır. Çünkü sert davranmak, öğrencilerde kötü alışkanlıklar yaratır. Şiddet gösterilerek eğitim verilirse, öğrencinin ruh sevgisini yok eder; onları tembelliğe sevk eder, onları yalancılığa iter. Kalblerinde sakladıklarının tersini söylemeye çalışırlar; içi başka dışı başka hale gelirler. Bu haller onlarda git gide karakter halini alır. Bundan dolayı öğretmenler çocuklara edep ve terbiye vereceğiz diye onlara karşı sert davranmamalıdırlar(Haldun 3.Cilt: 160).

Hz. Peygamber'in hadisleri ve tatbikatı, eğitimcinin kaba, sert ve haşin olmaması, aksine şefkat ve merhamet sahibi olmasını gerekli kılmaktadır(Ay 1997:46). Buna göre İslami eğitimde sevgi, merhamet ve pozitif disiplinin olması, eğitimin vazgeçilmezleri olarak değerlendirilmelidir.

Allah'ın Resulü kibar ve yumuşak huylu olduğu için etrafındakilere asla kaba davranmazdı, kimseyi hor görmezdi(Tirmizi 2015: 2.Cilt: 249). Allah Resulü’ nün varisleri olduğuna inanan öğretmenlerin de, öğrencilerine kaba davranmamaları ve öğrencilerini hor görmemeleri gerekmektedir.

İbni Sina'ya göre bütün dikkatin çocuğun ahlakını korumaya sarf edilmesi gerekir. Bu da çocukta aşırı sinir, şiddetli korku, üzüntü ve uykusuzluk bırakacak davranışlardan sakınmakla olur. Bunun yolu, her zaman çocuğun istediği şeyi göz önünde bulundurup onu yapmasını sağlamak; hoşlanmadığ 1 şeylerden de onu uzak tutmakla mümkündür. Bütün bunlar, çocuğun her emrine boyun eğmek için değil, onun hayatını kolaylaştırmak için yapılır(Çelebi 1974: 296).

Hiç şüphesiz ince, latif ve şefkatli bir eğitim, çoğu zaman çocukların istikamet üzere, temiz ve dosdoğru bir şekilde eğitilmesini sağlar. Fakat inceliği, latifliği ve şefkati gereğinden fazla olan bir eğitim de "disiplinsizliğe" neden olacağından, aşırı derecede zarar verir. Çünkü bu tür bir eğitim, doğru kıvamı bulunmayan bir benlik inşa eder(Kutup 2017:211).

Kabisi'ye göre, öğretmen işini yaparken, onlara güzel davranmalı ve onları kollayıp gözlemelidir. Öğretmenin her zaman surat asması, sevimsiz bir kabalıktır(akt. Işıkdoğan 2014). Sınıf yönetiminde asık suratın kabalık sayılması önemli bir husustur. Öğretmenin kaba davranması, sınıf yönetiminin kalitesini ve başarısını düşürür.

İbn Cemaa’ya göre, “Öğretmen güler yüzlü, iyilik ve yardımsever, öfke ve bencillikten uzak, sabırlı, başkalarını kendine tercih eden, iyiliğe teşekkür eden, komşularıyla iyi geçinen, öğrencilerine yumuşak davranan, akrabalarını seven biri olmalıdır. Öğretmen insaflı, adaletli, nazik davranmalı, gördüğü istenmeyen davranışları müsamaha ile karşılamalı ve yumuşaklıkla çözmeye çalışmalıdır. Kin, haset, kibir, riya, cimrilik, taassup, iftira, kaba söz, yalan, insanları küçük görmek gibi vasıflardan arınık olmalıdır. Çünkü bunlar, kötü ve kötülüklerin sebepleridir(Akt. Işıkdoğan 2014). Sınıf yönetimi istenmeyen davranışların yönetimini de içinde barındıran bir öğretmenlik davranışı olduğuna göre, öğretmenin sözü edilen bu kötü niteliklerden arınık olması sağlanmalıdır.

Osmanlı Türklerinde eğitim ağırlık merkezi dini eğitime dayanan bir sistemdi. Osmanlı eğitim sisteminin İslami eğitimin bir devamı olduğunu söylemek doğrudur. Medreselerde ve sibyan mekteplerinde çocukların dünyevi ihtiyaçlarını ön plana alan insan yetiştirme amacı güdülmemiştir. Bu sistemin felsefesine göre insanlar, bu dünyada misafïdi. Gerçek dünyaya ancak öldükten sonra ulaşılırdı ki, oradaki yerimizi bu dünyadaki iyi kötü davranışlarımız tayin ederdi. Cennete gidebilmek için bu dünyanın nimetlerine sırt çevirmek gerekirdi. "Bir lokma, bir hırkaya razı olup" her şey için hatta felaketler karşısında bile Allah'a şükredip, mütevekkil olmak gerekirdi. Cennete gitmek için bunları düşünen ve bunlara inanan Osmanlı Türkü, iyi terbiye görmüş bir insandı(Koçer, 1987; 5). Bu felsefe gerçekten de bir medeniyet algısının altyapısını oluşturmaktaydı. Eğitim sisteminin bütün sonuçları, bu felsefenin doğal sonuçları olarak ortaya çıkıyordu. Bundan dolayıdır ki, Tanzimat devrine kadar bizim terbiye sistemimiz tamamıyla dini, Tanzimat, Mutlakiyet ve Meşrutiyet devirlerinde dini-milli olmuştur (Ergin, 1977; 1638). Dini terbiyenin esasları, Kur'an'ın hükümlerine, Peygamberin sözlerine, fiillerine ve hareketlerine dayanır ve bütün Müslümanları kardeş sayar(Ergin 1977;1640). Buna göre, Tanzimat'tan önceki eğitim dönemi için “İslami eğitim/geleneksel eğitim” kavramını kullanmak yanlış olmasa gerek. Tanzimat'tan sonraki eğitim dönemi için de "Modern eğitim" kavramını kullanmak uygun düşer. Modern eğitim öncesi geleneksel eğitim, her tür eğitim çalışmasını yetke(otorite) ilkesine dayatan ve çocuğu toplumsal çevrenin kurallarına uymaya zorlayan bir eğitimdi. Bu dönemde daha çok 
geleneksel okuldan söz edilir. Karşıtı yeni eğitim, çağcıl eğitim( Öncül, 2000.) ya da "çağdaş eğitim" olarak kullanılır.

İslami eğitimde şiddetin öncelenmemesine rağmen, geleneksel eğitimin okullarında adeta bir istibdat idaresi yürürlükte olduğu ileri sürülmektedir. Mektep hocası elinde değneği ve falakasıyla bir çocuk cemaatinin adeta bir padişahıymış gibi keyif başında hükmeder ve çocuk ruhunun tabii isyanlarını ancak sopa kuvvetiyle bastırabilirdi. Yeni mektepte sopanın yerine itimat ve muhabbet kaim oldu. Yeni mektebin sınıfları adeta cumhuriyetle idare edilir hissini verir. Her çocuk benliğine ve izzet-i nefsine sahiptir. Muallim müşfik ve hayırhah bir reis-i cumhur gibi onları korur, irşat eder, korkutmadan saydırır. Emrettiğini hissettirmez. Yeni mektepte artık sopaya değil, başka ceza ve mükafat vasıtalarına da ihtiyaç kalmiyor(Resimli Gazete, Say1, 41, 14 Haziran 1341; Aktaran İ. Kara ve A. Birinci, 2005;447). Geleneksel eğitimin temel eğitim kurumları olan sibyan mekteplerinde ahlak eğitimi konusunda korkutma, ceza ve yıldırma esastı. Dayak başlıca eğitim aracı olarak kullanılıyor ve çocukların uslu, korkak ve olumsuz bir karakterde yetişmelerine sebep olunuyordu( Unat,1964; 7). Ahlak eğitimi için sağlanması gereken disiplinde dayak başlıca yöntem olarak kullanılıyordu. Oysa, Hz. Peygamber ve Kur'an'ın eğitim metodunda eğitimde şiddete(falakaya) rastlanmaması yanında, İslâm'ın ilk asırlarında da böyle bir uygulamaya tesadüf edilmemesi, onun İslâmî eğitimin bir gereği olmayıp, sonradan ortaya çıktığını göstermektedir. Ahmet Rasim'in eseri başta olmak üzere bu konudaki çeşitli hatıralardan derlenen bilgilerden hareketle, Osmanlı döneminde çocuklara önce Kur'an ve dini bilgilerin öğretildiğ $i$ eski mahalle mekteplerinin(sibyan okulları) kötülenmesi ve Cumhuriyet'ten sonra açılan okulların bunlardan üstün olduğunun vurgulanmasında korkunun ve şiddetin (falakanın) propaganda amacıyla kullanıldığı görülmektedir (TDV İslâm Ansiklopedisi, Cilt 12,1995).

İslâm eğitimcileri, fikirlerini genellikle Kur'an ve Sünnet' in ortaya koyduğu temel prensipler doğrultusunda açıklamışlar; ancak yaşadıkları dönemin şartlarına uygun olduğu gibi günümüz için de geçerli sayılabilecek pedagojik ve psikolojik nitelikli görüşler ortaya koymuşlardır. İslâm eğitimcilerinin, Batı eğitimcilerinden belirgin bir farkı vardır. $\mathrm{O}$ da, Batı eğitim sistemi içinde, genellikle Hristiyanlıktaki "aslî günah" düşüncesinden etkilenerek dayağı savunan pedagoglar olmasına karşılık, İslâm eğitimcileri arasında bu şekilde disiplini sağlamak için yegâne çarenin dayak olduğunu savunan herhangi bir eğitimci yoktur. Falaka İslam eğitim sistemine sonradan girmiş bir uygulamadır. Osmanlıların eğitimde en yüksek seviyeye ulaştığı XV-XVI. Asırda, eğitim kurumlarında falakaya yer verilmediği anlaşılmaktadır. Eğitim sisteminin bozulmaya yüz tuttuğu XVIII asırda eğitimde falakanın bir eğitim aracı olarak kullanıldığı görülmektedir. Falaka konusunun dinin özünden kaynaklanan bir uygulama olmadığı ve bu uygulamaya, bozulmaya yüz tutan sistemin getirdiği hatalı bir tatbikat örneği olarak bakmanın daha doğru olacağına inanılmaktadır. İslâm eğitim sisteminin(geleneksel eğitim) temelinde sevgi. Hoşgörü ve müsamaha vardır. Eğitimde sevgi, hoşgörü ve mükâfat, bir disiplin vasıtası olduğu kadar, ilgisiz kalma, korkutma ve gerektiğinde belirli sınırlamalara riayet ederek başvurulabilecek dayak cezası da bir eğitim ve disiplin vasitası olabilir. (Ay, Tarihsiz, 230-247).

Cumhuriyet dönemine kadar geleneksel ve modern eğitim kurumlarında eğitim yapıldı. İki kurum da zaman zaman alabildiğine karşısındakine muhalefet ederken ve eğitim-öğretim yöntemleri bakımından farklılaşırken, bazen de birbirine yakınlaşmıştır. Ancak benzer özelliklerden birisi modern ve geleneksel okullardaki disiplin ve cezalandırma uygulamaları olarak görüldü. Tanzimat'ın ürünü modern okullar, siyasi iradenin kesin taraf olmasıyla, geleneksel mektepler karşısında bazı yazar, edip ve eğitimciler tarafindan yüceltilmiştir. Bu süreçte mahalle mekteplerine ve diğer geleneksel okullara karşı kesin bir önyarg1 oluşturulmuştur. Ancak dönemin farklı okullarındaki gündelik hayata ilişkin anılar bu keskinliğ olabildiğince ortadan kaldırmakta ve bu kurumlar arasında pek çok ortak noktanın yaşatıldığını göstermektedir. $1847^{\prime}$ de çıkarılmış olan bir nizamname ile falaka ve dövmenin dinde olmaması nedeniyle yasaklanmıştır. 1847 'den itibaren bütün okullarda başta falaka olmak üzere bedensel ve şiddete dayalı her türlü cezanın kâğıt üzerinde yasaklandığı görülür. 1892 yılında çıkarılan başka bir nizamnameye göre de okullardaki fiili cezaların hepsi yasak edilmiştir. Falaka cezasının hem klasik hem de modern okullarda, hem merkezde hem taşrada ilk ve ortaöğretimin hemen bütün kurumlarında uygulandığg görülmüştür. Yazılı metinlerdeki ifadeler, bugününü çağdaş eğitim değerlerinden hiç de geri değildir. Kuramsal alt yapının iyi oluşturulmasına rağmen, uygulamada çok geri kalındığı açıtır. Eğitim sisteminde gücünü yazılı ilkelerden değil, geleneksellikten ve sözlü kültürden alan bir sistemin işlediği görülmektedir. Son dönem Osmanlı eğitiminde açılmış pek çok okulda zihniyetin büyük ölçüde geleneksel devam ettiği söylenebilir. Eğitim sistemindeki şiddetin toplumun zihniyet yapısıyla ilişkili olduğu açıktır. Her ne kadar din ve kutsal metinler dayağı yasaklamışsa da toplum, şiddeti zımnen desteklemekte, hele mesele eğitim, ilim ise şiddet adeta meşrulaştırılmaktadır. Bu toplum; "Hoca dediğin böyle olmalı, elinden sopa düşmemeli", "Kızını dövmeyen dizini döver”, "Hocanın vurduğu yerde gül biter", "Hocanın vurduğu yeri cehennem yakmaz", "Dayak cennetten çıkmadır", "Eti senin kemiği benim" gibi söylemler üretmiş, bunları darbı mesel haline getirmiş ve gereklerine riayet etmiştir. 
(Gündüz, 2010). Bu darbı mesellerin dini hiçbir referansı olmadığı açıktır. Okul disiplini konusunda dayağın zorunluluklar tahtında kullanılması, İslam pedagoglarını bir hayli meşgul etmiş, fakat genellikle cezanın ıslah vazifesi üzerinde durulduğu gibi, özellikle, yaşları bakımından sorumluluk hudutlarına girmeyen çocuklar üzerinde dayak cezasının tatbikinden sakınılmıştır. İslami eğitimde aslolan yumuşak bir yaklaşım ile muamele ve ıslah-1 nefis cezasıdır. Kesinlikle İslam, eğitimde cezayı önceleyen bir uygulamayı uygun görmez.

Osmanlı'da ana-babalar çocuklarını hocaya teslim ederken elini öptürürler ve "eti senin kemiği benim" derlerdi. Bu sözle hocaya, çocuklarını dövebileceğini ifade etmiş olurdu( Akyüz, 2010: 90). Bu sözün esas anlamı şu olsa gerek: Hocam ben sana güveniyorum; bu çocuğumu yetiştirmen konusunda tam yetkilisin. Yoksa "al bu çocuğu döv, geri kalanı bana yeter" asla değildir.

Dayak eğitimin en önemli aracı olarak görülür, hoca da çocukları, tokatla, değnekle, falaka ile döverdi. Toplumda yaygın bir deyiş vardı: "Hocanın vurduğu yerde gül biter." Çocukların, üzerinde Kur'an okudukları rahlelere de İranlı Sadi'nin şu ünlü mısraının yazıldığı olurdu: Öğretmenin cefası, babanın şefkatinden daha iyidir(Akyüz 2010: 90-91). Bu durum sadece Osmanlı eğitim sistemi için değil çağın bütün toplumları için geçerli idi. Nitekim, 16. yüzyılda Türkiye'ye gelen bir Alman gezgini, hocanın çocuğa ihtimam ve sabırla davrandığını, gerektiğinde de insaflı şekilde dövdüğünü, oysa o çağlarda Avrupa'da dayağın daha acımasızca uygulandığını söyler: Çocuk yere yatırılıp değnekle dövülür, fakat kamçı kullanılmaz ve o, Hıristiyanların yaptı̆̆ı gibi sakatlanmaz(Akyüz 2010; 91).

Buna rağmen, Türkiye'de fiziksel cezaların terbiye yöntemi olarak algılanması, eğitimde dayağın gelenekselleşmiş bir yere sahip olması, dayağın kanıksanan bir davranış olarak algılanmasına ve fiziksel cezanın kamusal alanda meşru olarak kabul edilmesine neden olmuştur(Akyüz 2015).

Günümüz eğitim siteminde dayağın ve şiddetin mevzuatta yasaklanmış olması, bu davranışların eğitimden fiilen kalkmış olması anlamına gelmez. Nitekim zaman zaman bu yanlış davranışların okullarda yaşandığına ilişkin haberleri takip ediyoruz.

Çok eskiden beri Doğu ve Müslüman toplumlarında dayak bir öğretim ve disiplin aracı idi(Akyüz 2010: 91). Bu yarg1, eğitim tarihi gerçeklerine uygun görünmemektedir. Nitekim Fransız düşünür Montaigne, 1580 'de ülkesinin çocukları için şöyle der: "Dayaktan sakatlanmış, sersem olmuş nice çocuklar vardır. Devletimizin kanunları yine bu işe karışmaz. Sanki bu sakatlar ve sersemler bizim toplumumuzda yaşamıyorlar. Neden babaları ve çocuğu eğiten herkesi, öfkeli iken çocukları dövmekte serbest bırakıyoruz(Montaigne, 2001: 137). Burada öğretmenlerin, babaların çocukları dövmesinden çok, öfkeli iken dövmemesi üzerinde durulduğu görülmektedir. Bu durum, tarihsel gerçeklerin, çocuk eğitiminde, Doğu ve Batı ayrımı yapılmamasını gerekli kılmaktadır.

Günümüz eğitimcilerinin de bu konudaki görüşleri özetle şöyledir: Kabul etmeliyiz ki, dayak etkili bir disiplin aracıdır. ABD’nin 46 eyaletinde dayak ceza olarak uygulanabilir bir yöntemdir. Amerikan yüksek mahkemesi, birçok kez öğretmenin öğrencileri dövmesinin eğitim gereği olduğunu ve Anayasaya aykırı olmadığına karar vermiştir. Amerika'da öğretmenler arasında yapılan araştırmalar, çoğunluğun dayağı onayladığını ortaya koymaktadır. ABD Main eyaletinde okullarda dayak yasaklanınca, anababalar yasağın kalkması için kampanya açmışlar(Yörükoğlu, 1984; 112-114).

\section{Sonuç}

İslami eğitimin kaynakları olan Kur'an, sünnet ve İslâmî eğitim alanyazını, öğretmenlerin disiplin anlayışlarına ilişkin çok açık önerileri barındırmaktadır.

İslami/geleneksel eğitimin temel kaynağı olan Kur'an ve Sünnete göre, Allah Resulü(S.A.) Müslümanlara gönderilmiş bir eğitimci, bir öğretmendir. Bir öğretmen olarak gönderilen Allah Resulü(S.A.), merhamet ederek öğretmenlik yaptığının altını çizerek, öğretmen olarak merhamet edersek, öncelikle öğrencilerden olmak üzere, herkesten merhamet göreceğimize vurgu yapmaktadır.

Okul disiplini konusunda dayağın zorunluluklar tahtında kullanılması, İslam pedagoglarını bir hayli meşgul etmiş, fakat genellikle cezanın ıslah vazifesi üzerinde durulduğu gibi, özellikle, yaşları bakımından sorumluluk hudutlarına girmeyen çocuklar üzerinde dayak cezasının tatbikinden sakınılmıştır. İslami eğitimde aslolan yumuşak bir yaklaşım ile muamele ve sslah-1 nefis cezasıdır. Kesinlikle İslam, eğitimde cezayı önceleyen bir uygulamayı uygun görmez. Çünkü Kur'an ve sünnet, eğitimde sevgi ve ödülü önceler. Buna rağmen geleneksel eğitimde uygulanan şiddet örnekleri, İslam inancından kaynaklanan uygulamalar olduğu yönündeki yargılar, olumsuz propaganda amacına yönelik iddialar olarak değerlendirilmelidir.

İslami eğitimde çocukların cezalandırılabileceğine ilişkin ruhsat olmasına rağmen, cezanın İslami eğitimde kullanılması önerilmez. Hz. Peygamber'in çocukların -yaptıkları yanlış hareketten sonra bilebaşını okşaması son derece önemlidir. Hz. Peygamber çocukları her zaman sevmiş, onların sevilmesini, öpülüp okşanmasını, onlara şefkat ve merhamet gösterilmesini istemiştir. Bu öneri, İslami eğitimde 
disiplinin sevgiye dayalı olarak tesis edilmesini ögütlemektedir. Bu öneriye uymayan her türlü davranış, İslami eğitimin disiplin anlayışına aykırıdır.

Başta İbni Haldun ve Gazali olmak üzere birçok İslâm bilgini, eğitimde istenmeyen bir davranışı yönetirken, doğrudan doğruya hakaret mahiyetinde bir tepki kullanmamayı, ima ve şefkat yolu ile istenmeyen davranışı yönetmeyi ve istenmeyen öğrenci davranışını önlemede de bu yolun izlenmesi gerektiğine vurgu yapmaktadır.

Eğitim öğretim işlerinde öğrencilere, bilhassa küçük yaştaki çocuklara sert davranmak zararlıdır. Çünkü bu sert davranmalar, öğrencilerde kötü bir alışkanlık yaratır. Bu türlü eğitim öğrencinin ruh ve yaradılışına baskı yapıp onların neşesini, iş ve çalışma sevgisini yok eder ve onları tembelliğe ve kızgın ellerin kendilerine uzanmasından korkarak, yalana ve kötülüğe sevk eder. Git gide bu haller adet ve karakter haline gelir. Bundan dolayı öğretmen, anne ve babalar edep ve terbiye vereceğiz diye çocuklara sert davranmamalıdırlar. Tesis edilecek disiplinin çocuğun onuruna uygun iç disiplin olması, İslami eğitimin doğasına daha uygun düşmektedir.

Günümüz eğitim siteminde dayağın ve şiddetin mevzuatta yasaklanmış olması, bu davranışların eğitimden fiilen kalkmış olması anlamına gelmez. Nitekim zaman zaman bu yanlıs davranışların okullarda yaşandığına ilișkin haberleri takip ediyoruz. Disiplinin sağlanması ve şiddete başvurmadan eğitimin sürdürülebilmesi için yasal değişikliklerden çok, zihniyet değişiminin gerçekleşmesi zorunludur. Zihniyet değişiminin en çok eğitimde ve eğitimin disiplin ve sınıf yönetimi alanında gerçekleştirilmesi, eğitimin kalitesini artıracaktır. Disiplinin olması gerekir. Sorun bunun nasıl olacağ 1 ile ilgilidir. Disiplinin dışardan değil, içerden olması gerektiği hususunda, günümüz eğitimcilerinin ortak bir görüşe sahip oldukları söylenebilir. İslami eğitimde şiddetin olağan kabul edilmesi, bilimsel gerçeklerle bağdaşmadığ 1 açıkça görülmektedir. Geçmişte, eğitimde otoritenin otoriterliğe evrilmiş olması, İslami eğitimin değil, toplum zihniyetinin doğal bir sonucu olarak kabul edilmelidir. Nitekim eğitimde disiplin sorunu günümüzde de daha yoğun bir biçimde varlığını sürdürmektedir.

\section{Kaynakça}

Ay, M. E. “İslâm'da Aile ve Çocuk Terbiyesi”, Tartış̧alı İlmi Toplantılar Dizisi 18, İslami Araştırmalar Vakfı Yayınları, Tarihsiz.

Akyüz, E. (2015), Çocuk Hukuku ve Çocukların Hakları ve Korunması, Ankara: Pegem Yayınları

Akyüz, Y. (2010), Türk Eğitim Tarihi, Ankara: PEGEM Yayınları,

Alaylığlu, R. A.Ferhan Oğuzkan, (1976), Eğitim Terimleri Sözlüğü, İstanbul

Ayasbeyoğlu, N.(1991). İslamiyet'in eğitimimize getirdiği değerler ve Kur'an-ı Kerim'in eğitimle ilgili ayetlerinin tahlili, İstanbul, M.E.B. Yayınları

Balaban, M.R.(1974). İlim-Ahlak-İman, Ankara: DİB Yayınları

Başar, H.(2012), Sınıf Yönetimi, İstanbul: Morpa Yayınları

Bayraktar, M.F. (1987), İslami Eğitimde Öğretmen-Öğrenci Münasebetleri, İstanbul: M.Ü.İ.F. Yayınları, 1987

Balme, C. ve Bennis, D.(2008). Alternatif eğitim, Editör: Matt Hern (Çev.Eylem Çağdaş Babaoğlu), İstanbul: Kalkedon yay.

Binbaşığlu, C.(1986),Genel Öğretim Bilgisi, Ankara: Binbaşığlu Yayınları

Çelik, V. (2003), Sınıf Yönetimi, Ankara: Nobel Yayınları

Çelebi, A.(1974). İslam'da Eğitim Öğretim Tarihi, (Çev. A. Yardım), İstanbul: Damla Yayınları 
Erdem, A. R.(2010), “Sınıf Disiplini ve Kuralları”, Sınıf Yönetimi, (Editör: R. Sarpkaya), İstanbul: İhtiyaç Yayınları

Ergin, O.(1977), Türk Maarif Tarihi, Cilt 5, İstanbul: Eser Matbaası, 1977

Erzurum, H. H. ve İ. Kır,(2011), “İlköğretim Öğretmenlerinin Kullandıkları Disiplin Türleri”, Mustafa Kemal Üniversitesi Sosyal Bilimler Enstitüsü Dergisi, Sayı 16

Gordon, T. (2001), Çocukta Dış Disiplin Mi? İç Disiplin Mi?”, (Çev. Emel Aksay), İstanbul: Sistem Yayıncilik

Haldun, İ. Mukaddime, 3. Cilt.(Çev.Z. K.Ugan), İstanbul: Milli Eğitim Basımevi

Hesapçığlu, M.(1988), Öğretim İlke ve Yöntemleri, İstanbul: Beta Yayınları, 1988

Huth, R. (2015).“A Strategy for Classroom Success”, Jurnal on Best Teaching Practices, June Vol. 2, Issue 2).

Kara, İ. ve A. Birinci, (2005), Mahalle/Sibyan Mektepleri, İstanbul Dergâh Yayınları, "Resimli Gazete, Sayı, 41, 14 Haziran 1341"

Kabisi(1966). İslam'da Öğretmen ve Öğrenci Meselelerine Dair Geniş Risale,(Çev. S.Ateş ve H.R.Öymen), Ankara: A.Ü. Basımevi

Khan, S. Dünya Okulu,(2018), (Çev.Cem Akaş), Yapı Kredi Yayınları, İstanbul

Koçer, H.K.(1987), Türkiye'de Modern Eğitimin Doğuşu, Ankara: Uzman Yayınları

Kur’an-ı Kerim ve Türkçe Açıklamalı Meali; Heyet

Kutup, M.(2017). İslami Eğitim Metodu,(Çev. M. B. Eryarsoy), İstanbul: Beka Yayınları

Küçükahmet, L, (1994), Öğretim İlke Yöntemleri, Ankara: Gazi Büro Kitabevi

Mansor, A. N. Eng,W. K. Rasul, M.S. Izham, M. Hamzah, M. ve Aida Hanim A. Hamid, A. H. A. (2012). "Effective Classroom Management", İnternational Education Studies; Vol.5, No.5.

Montaigne, Denemeler, 2001, (Çev. Sebahattin Eyüpoğlu), İstanbul: MEB Yayınları

Okutan, M. (1997), Genel Öğretim Metodları, Trabzon

Oğuzkan,F.(1981), Eğitim Terimleri Sözlüğü, Ankara: TDK Yayınları

Öncül, R. (2000), Eğitim ve Eğitim Bilimleri Sözlüğü, İstanbul: MEB Yayınları

Özbek, A.(1994). Bir Eğitimci Olarak Hz. Muhammed, Konya: Esra Yayınlar

Russell, B.(2003), Sorgulayan Denemeler, (Çev. Nermin Arık), Ankara: TÜBİTAK Yayınları

Seven, Ö. Altınışık, S. Ve Elmas A.(2018). "Türk Hukukunda Öğretmenlerin Disiplin Hakkı," İnternational Journal of Disiplines Economics\&Administrative Sciences Studies, Vol. 4

Şimşek, Ö. F. (2004)“Bir Gurup Rehberliği Programının Öğretmenlerin Disiplin Anlayışına Etkisi”, AÜEBF Dergisi, Cilt 37; Sayı 2.

TDV, İslâm Ansiklopedisi, Cilt 12 
TDV, İslam Ansiklopedisi, Cilt 39

Unat, F. R.(1964), Türkiye Eğitim Sisteminin Gelişmesine Tarihi Bir Bakış, Ankara: MEB Basımevi

Yılmaz. M. (2010).“ Din öğretiminde sınıf yönetimi”, Etkili Din Öğretimi, (Ed. Şaban Karaköse), İstanbul, TİDEF Yayınları

Yörükoğlu, A. (1984), Değișen Toplumda Aile ve Çocuk, Ankara: Aydın Kitabevi Yayınları, 1984

Ziglar, Z. (1998).Olumsuz Bir Dünyada Olumlu Çocuklar Yetiştirmek, (Çev. Suer, E. Ö.), İstanbul: Beyaz Yayınları 